\title{
VYBRANÉ OTÁZKY VYUŽITELNOSTI SOUKROMOPRÁVNÍCH NÁSTROJŮ K OCHRANĚ ŽIVOTNÍHO PROSTŘEDÍ*
}

\author{
JAN VÉVODA
}

\section{Abstract: $\quad$ Usability of Selected Private Law Instruments of Environmental Protection}

The aim of this article is to provide a reader with a brief analysis of the possibilities of using the fundamental private law instruments for the purpose of protection of the environment. The analysis is carried out from the perspective of an individuals who use these instruments to protect their rights and interests.

This article focuses on 3 selected private law instruments, namely the protection of the personality, neighbourhood law, and the prevention and compensation of damage. Special attention is paid to issues such as right to live in a favourable environment, which is a new institute in the Czech civil law. Within a scope of neighbourhood law the problem of proportionality of imissions to local circumstances, relation between private and public law regulation governing activities causing imissions and possibilities of protection against noise caused by road traffic are subject of closer study. Changes in legal regulation of general prevention of damage and in liability for damage to forest caused by industrial exhalations are also discussed.

In conclusion it can be stated that private law instruments are usable for the protection of the environment, but the protection is only indirect and not complex. For this reason, these tools cannot replace public environmental law, but they can be a valuable addition to it.

Keywords: private law; protection of environment; protection of personality; neighbourhood law; compensation of damage

Klíčová slova: soukromé právo; ochrana životního prostředí; ochrana osobnosti; sousedské právo; náhrada škody

DOI: $10.14712 / 23366478.2020 .3$

\section{1. ÚVOD}

Ochrana životního prostředí je bezesporu veřejným zájmem, jehož garantem je především stát, jak vyplývá např́iklad z čl. 7 Ústavy České republiky. ${ }^{1}$ Jeho prosazování však nemusí být přenecháno výlučně veřejné moci, obzvláště v případě

* Tento článek vychází ze zjištění a závěrů autora obsažených v jeho disertační práci na téma „Soukromoprávní nástroje ochrany životního prostředí“, která byla v zárí 2018 obhájena na Právnické fakultě Univerzity Karlovy.

1 Ústavní zákon č. 1/1993 Sb., Ústava České republiky. Pokud není uvedeno jinak, jsou všechny právní předpisy citovány v jejich znění aktuálním k 29. ř́ijnu roku 2019. 
životního prostředí by jeho ochrana měla být zájmem nás všech. Je to dáno jeho povahou stejně jako povahou člověka jako živého tvora, pro kterého je funkční mechanismus planety Země a její biosféry conditio sine qua non přežití i dalšího vývoje. ${ }^{2}$ Ostatně podle Ústavního soudu ,v demokratickém právním státě je životni prostředí hodnotou, jejiž ochrana má být realizována za aktivní participace všech složek občanské společnosti“ ${ }^{3}$ Přestože $\mathrm{v}$ tomto př́padě zmíněná slova mířila především na adresu právnických osob, zejména spolků a dalších nevládních organizací angažovaných v ochraně životního prostředí, domnívám se, že není důvod, proč by neměla platit na soukromé subjekty obecně. Obdobnou myšlenku rozvíjí i J. Blahož, když uvádí, že „,ponechání péče o životni prostředi pouze státu a nadstátním a mezinárodním organizacím pojetí demokratického liberálního státu odporuje. Rovněž člověk a občan zcela přirozeně nadaný nejvýznamnějšimi hodnotami demokratické společnosti - základnimi lidskými a občanskými právy - by mél být strážcem zdravého životního prostředí. “4

Soukromá iniciativa za účelem ochrany životního prostředí může být motivována dvěma hlavními důvody. Na prvním místě je jistě žádoucí zmínit ušlechtilé důvody pramenící z uvědomění si významu životního prostředí a jeho hodnoty přesahující lidská měřítka. Nosnou myšlenkou nyněšsího pojednání je ale úvaha, že za rozhodnutím podniknout kroky vedoucí k ochraně životního prostředí může stát i podstatně sobečtější motivace.

Zřejmě není třeba blíže rozebírat, že zhoršená kvalita životního prostředí se může podepsat na lidském zdraví, přičemž ovlivňuje i další aspekty života, jako je soukromí, bezpečí a klid domova. Ochranu soukromého vlastnictví pak s ochranou životního prostředí spojuje skutečnost, že případné poškození jednoho je zároveň i poškozením druhého, nebo alespoň v důsledku $\mathrm{k}$ němu vede. Tedy např́klad nelegální vytěžení lesa patřícího někomu jinému způsobuje tomuto vlastníkovi bezpochyby škodu, zároveň však dochází $\mathrm{k}$ poškození významného krajinného prvku$^{5}$ a jedné $\mathrm{z}$ důležitých složek životního prostředí. Může nastat ale i opačná situace, kdy z důvodu znečištění ovzduší průmyslovými exhalacemi dochází k poškození lesů, přičemž vzniká též škoda na soukromém majetku vlastníka poškozeného lesa.

Soukromé právo je dle $\S 1$ odst. 1 věty první občanského zákoníku 6 tvořeno těmi ustanoveními právního řádu, která upravují vzájemná práva a povinnosti osob. Tato definice na první pohled nenabízí mnoho prostoru $\mathrm{k}$ tomu, aby bylo v rámci této právní disciplíny pamatováno na ochranu životního prostředí. Soukromé právo však spočívá mimo jiné na zásadách, že každý má právo na ochranu svého života a zdraví, stejně jako na zákonné ochraně vlastnického práva. ${ }^{7}$ Právě tyto hodnoty mohou být dotčeny v důsledku zhoršené kvality životního prostředí, přičemž osoba, která by je chtěla ve

\footnotetext{
Viz § 2 zákona č. 17/1992 Sb., o životním prostředí.

Usnesení Ústavního soudu ze dne 28. června 2005 spis. zn. I. ÚS 486/04.

BLAHOŽ, J. Právo na životní prostředi - mezi antropocentrismem a ekocentrismem. In: MÜLLEROVÁ, H. a kol. Právo na př́znivé životni prostředi: Nové interpretační pristupy. Praha: Ústav státu a práva AV ČR, 2016, s. 42.

5 Viz $§ 3$ odst. 1 písm. b) zákona č. 114/1992 Sb., o ochraně př́rody a krajiny.

6 Zákon č. 89/2012 Sb., občanský zákoník (dále též jen „občanský zákoník“ nebo „,nový občanský zákoník").

7 Viz $§ 3$ odst. 2 písm. a) a e) občanského zákoníku.
} 
vlastním zájmu či zájmu svých blízkých bránit, musí vystoupit proti zdroji jejich ohrožení. Tím se může i nepřímo angažovat ve prospěch životního prostředí.

Toto pojednání je proto zaměřeno na tři klíčové instituty upravené v českém občanském zákoníku, a to ochranu osobnosti, ochranu před imisemi v rámci sousedského práva a předcházení a náhradu škod, nebot’ se jedná o nástroje, které má k dispozici jednotlivec, aby se bránil před dopady zhoršování životního prostředí do své osobní a majetkové sféry. ${ }^{8}$

Účelem analýzy využitelnosti institutů soukromého práva k ochraně životního prostředí není nalezení alternativy, která by mohla nahradit převažující veřejnoprávní nástroje. Neumožňují totiž např́iklad adekvátně reagovat na rozsáhlejší problémy životního prostředí, nebot' ty nejsou řešitelné na půdorysu sporu žalobce proti žalovanému. Nemusí jít přitom o otázky rozměru globální změny klimatu, obtížně představitelný je i soukromoprávní postup proti znečišt'ování ovzduší pocházejícímu ze spalovacích stacionárních zdrojů umístěných v domácnostech. Soukromoprávní prostředky nemohou postihnout ani environmentální problémy projevující se mimo osobní či majetkovou sféru, zejména ve vztahu k nevlastnitelným složkám životního prostředí, jako jsou např́iklad populace volně žijících živočichů (s výjimkou možnosti vlastnickoprávní ochrany jejich stanovišs').

Domnívám se, že má ale smysl se na soukromoprávní nástroje zaměřit z toho důvodu, že mohou posloužit $\mathrm{k}$ doplnění prostředků nabízených veřejným právem, nebot' životní prostředí je hodnotou, na jejiž ochranu je žádoucí využít všechny dostupné prostředky při zapojení co nejširšího okruhu lidí. Cílem je zároveň též ukázat, že pokud se lidé budou brát o vlastní štěstí, ${ }^{9}$ nemusí to být na úkor životního prostředí, ale v některých prípadech naopak $\mathrm{v}$ jeho prospěch.

\section{OCHRANA OSOBNOSTI}

Z nástrojů, s jejichž pomocí mohou soukromé osoby v rámci ochrany svých zájmů prrispívat též $\mathrm{k}$ ochraně životního prostředí, je dle mého názoru nezbytné na prvním místě zmínit téma ochrany toho pro každého člověka nejzákladnějšího a nejvlastnějš́ího - tedy jeho osobnosti. Environmentální souvislosti lze nalézt v následujících aspektech osobnostních práv:

8 Pokud se jedná o soukromoprávní souvislosti ochrany životního prostředí, velmi často bývá zmiňována právní úprava sloužící k omezením vlastnického práva z environmentálních důvodů (omezení užívání i o různá dispoziční omezení), představuje ale nástroje v rukou státu a nikoli jednotlivců. Soukromé právo též nenabízí specializované smluvní instrumenty využitelné k ochraně životního prostředí, takže v případě smluv, které by snad na toto téma mohly být uzavřeny, půjde pouze o potvrzení dohody, kterých bylo dosaženo mimoprávními postupy, a to s problematickou vynutitelností. Z analýzy jsou vynechány i procesní nástroje, které si zaslouží samostatnou analýzu, jež by svým rozsahem a zaměřením překračovala možnosti tohoto pojednání. Zejména mám v tomto ohledu na mysli v současnosti diskutovanou hromadnou žalobu. Zákon, který by ji měl zavést do českého právního řádu, ostatně dosud čeká na předložení Parlamentu.

9 Ustanovení § 3 odst. 1 občanského zákoníku. 
Souvislost ochrany osobnosti člověka, jak ji pojímá v rámci svých ustanovení občanský zákoník, s ochranou životního prostředí, spočívá v prvé řadě v oblasti ochrany života a zdraví a také soukromí. Právě v těchto oblastech se vůči člověku může nejblíže, resp. nejintenzivněji projevit zhoršení kvality životního prostředí, např́klad v důsledku znečištění ovzduší či hlukové zátěže, což může mít zdravotní dopady či narušovat možnost využíání obydlí či jiné realizace soukromého života.

Určité nastínění environmentální stránky ochrany osobnosti může při nedostatku české judikatury nabídnout rozhodovací praxe Evropského soudu pro lidská práva. Ostatně i komentář T. a A. Doležalových zdůrazňuje, že ,koncepci ochrany osobnosti, a s tím souvisejicí fyzické a morální integrity, je nutno v současné době zasadit do kontextu Úmluvy o ochraně lidských práv a základnich svobod“".10 Štrasburský soud totiž i přes absenci výslovného zakotvení práva na př́iznivé životní prostředí (či jeho podobně formulovaného ekvivalentu) nalezl řešení, pomocí kterého dokáže $\mathrm{v}$ určitých př́ipadech poskytnout ochranu i v záležitostech environmentální povahy. Je tomu tak proto, že nachází př́islušný interpretační prostor zejména v ustanovení Úmluvy o ochraně lidských práv a základních svobod věnovaném právu na respektování soukromého a rodinného života a obydlí. ${ }^{11} \mathrm{~S}$ jejich pomocí je tak právo na př́iznivé životní prostředí chráněno nepř́mo, s využitím jiného ( $v$ úmluvě upraveného) institutu, tzv. par ricochet. ${ }^{12} \mathrm{Za}$ jednoznačný př́iklad tohoto př́stupu může být považován rozsudek ve věci Moreno Gómez týkající se čl. 8 Úmluvy, v němž Evropský soud pro lidská práva dospěl k závěru, že „porušení práva na respektováni obydlí se neomezují na konkrétní nebo fyzická narušení, jako je nedovolený vstup, nýbrž také zahrnuji ta porušení, která nejsou konkrétní či fyzická, jako hluk, emise, pachy nebo jiné formy rušeni". ${ }^{13}$ Problematika rušení hlukem, pachem a dalšími podobnými vlivy již má jednoznačné souvislosti s ochranou životního prostředí. ${ }^{14}$

10 DOLEŽAL, T. - DOLEŽAL, A. In: MELZER, F. - TÉGL, P. a kol. Občanský zákoník-velký komentár. Svazek I. § 1-117. Praha: Leges, 2013, s. 518. Samotná Úmluva o ochraně lidských práv a základních svobod byla vyhlášena sdělením federálního ministerstva zahraničních věcí ČSFR č. 209/1992 Sb.

11 Jedná se o čl. 8 Úmluvy o ochraně lidských práv a základních svobod. Z jiných práv upravených touto úmluvou je v dané souvislosti relevantní právo na život dle čl. 2, které v judikatuře přichází na pořad především v případech různých havárií (např. rozsudek Evropského soudu pro lidská práva ve věci Öneryildiz proti Turecku z 30. listopadu 2004, č. stížnosti 48939/99). Naopak čl. 3 Úmluvy zakazující nelidské či ponižující zacházení př́liš uplatnění v environmentálních kauzách nedojde (např. v rozsudku ve věci López Ostra proti Španělsku z 9. prosince 1994, č. stížnosti 16798/90, Evropský soud pro lidská práva odmítl, že by i velmi obtížné životní podmínky zakládaly ponižující zacházení.

12 REPÍK, B. Chrání Evropská úmluva o lidských právech právo na životní prostředí? Bulletin advokacie, 2005, č. 7/8 a 9, s. 23. Jak uvádí autor zmíněného článku, ,použití tohoto postupu rozšiřujícího rozsah Úmluvou chráněných práv není v praxi býv. Komise a Soudu vzácné.

13 Rozsudek Evropského soudu pro lidská práva ve věci Moreno Gómez proti Španělsku z 16. listopadu 2004, č. stížnosti 4143/02.

14 Lze pro ilustraci zmínit, že Evropský soud pro lidská práva se věnoval také problematice dopadů průmyslové výroby na osoby žijící v okolí (např. rozsudek Evropského soudu pro lidská práva ve věci Fadeyeva proti Rusku z 9. června 2005, č. stížnosti 55723/00), negativním vlivům nadměrné silniční dopravy (např. Rozsudek Evropského soudu pro lidská práva ve věci Deés proti Mad’arsku z 9. listopadu 2010, č. stížnosti 2345/06). 
Pokud se jedná o možné dopady zhoršení životního prostředí na lidské zdraví, nelze se dle mého názoru omezit jen na fyzické aspekty lidského bytí, ale je třeba pamatovat i na stránku duševní, intelektuální či naopak emocionální. I ve vztahu k ochraně lidského zdraví lze připomenout, jak tento pro člověka jeden z nejcennějších statků v nejobecnější rovině definuje světová zdravotnická organizace, podle níž je zdraví „stavem úplné fyzické, duševni a sociální pohody a nikoli pouze neprítomnost nemoci nebo zdravotního postiženi" ${ }^{15}$ Je tedy možné si položit otázku, zda by bylo z hlediska právní úpravy ochrany osobnosti myslitelné, aby byla osobnost člověka zásahem do životního prostředí dotčena $\mathrm{v}$ psychologické rovině.

Nelze též zapomínat na to, že fyzické a duševní zdraví jsou v úzkém propojení a narušení jednoho se může negativně projevit i na druhé zmíněné složce. Uvažovat lze v tomto případě zejména o důsledcích nežádoucích zásahů do krajiny narušujících prostředí, v němž se odehrává život člověka, a to nikoli ve významu zdroje látek nezbytných k životu (a potenciálního nosiče látek životu nebezpečných), ale jako místa k odpočinku, pramene inspirace a estetických prožitků nebo jako určitého životního záchytného bodu a protikladu k mnohdy stresujícímu životu v moderní civilizaci. Ostatně i zákon o ochraně př́rody a krajiny pracuje s pojmy vzhled či estetika a pamatuje na lidskou potřebu občas se vydat do př́rody. ${ }^{16}$

\subsection{PRÁVO ŽÍT V PŘÍZNIVÉM ŽIVOTNÍM PROSTŘEDÍ}

Nový občanský zákoník přinesl v oblasti ochrany osobnosti významnou změnu, nebot' právě jeho $§ 81$ obsahuje jednu z mála opravdu výslovných zmínek o životním prostředí. ${ }^{17} \mathrm{~V}$ demonstrativním výčtu hledisek, z nichž je lidské osobnosti ochrana poskytována, se totiž vedle života a důstojnosti člověka, jeho zdraví či soukromí hovoří o jeho právu žít v př́źznivém životním prostředí. ${ }^{18}$ Možnost hodnotit využitelnost tohoto práva je ale limitována absencí jakékoli konkrétnější právní úpravy, která by naznačila rozsah tohoto práva, i nedostatkem judikatury.

15 Ústava Světové zdravotnické organizace [online]. Světová zdravotnická organizace, 1946 [cit. 7. 1. 2018]. Dostupné z: http://www.who.int/about/mission/en.

16 Např. podle $\S 2$ odst. 1 zákona o ochraně přírody a krajiny je součástí ochrany přírody a krajiny též „péče o vzhled a př́stupnost krajiny“", $\S 8$ odst. 1 zase připomíná estetický význam dřevin, který musí být vyhodnocován $\mathrm{v}$ procesu povolávání jejich kácení. § 63 odst. 2 pak upravuje př́istup do krajiny jako právo každého vstupovat na pozemky zejména ve veřejném vlastnictví, samozřejmě za podmínky dodržení řady pravidel (mimo jiné se nesmí při využívání průchodu přes cizí pozemky zasahovat do práv na ochranu osobnosti). Podobně s právem na vstup do přírodního prostředí počítá též § 19 zákona č. 289/1995 Sb., o lesích a o změně a doplnění některých zákonů (lesní zákon).

17 A dle mého mínění jedinou, která by mohla být pro účely ochrany životního prostředí relevantní. Je pravdou, že zmínku o životním prostředí lze v občanském zákoníku nalézt též v ustanovení § 2851, které je však věnováno postupu při řešení pojistné události, a § 2976 a 2987 upravující skutkovou podstatu nekalosoutěžního jednání „ohrožení zdraví nebo životního prostředi““. V tomto druhém př́ípadě je ohrožením životního prostředí míněno porušení pravidel jeho ochrany vyplývajících z veřejného práva.

18 Konkrétní vysvětlení, proč bylo do demonstrativního výčtu hodnot, které jsou v rámci ochrany osobnosti chráněny, doplněno právo žít $\mathrm{v}$ příznivém životním prostředí, důvodová zpráva $\mathrm{k}$ návrhu občanského zákoníku nenabízí, na druhou stranu je třeba připomenout, že nejde o myšlenku nijak novou. Objevuje se totiž již v literatuře věnované předchozí právní úpravě ochrany osobnosti, která byla obsažena $\mathrm{v} \S 11$ starého občanského zákoníku. 
H. Müllerová ve svém pojednání věnovaném právu žít v př́íznivém životním prostředí ${ }^{19}$ zmiňuje př́pad, završený až rozsudkem Nejvyššího soudu z roku $2016,{ }^{20}$ který nabízel skutkové okolnosti, které mohly být zajímavým podkladem pro vyzkoušení funkčnosti žaloby na ochranu osobnosti ve výše nastíněném směru. V tomto sporu žalobce požadoval náhradu škody a též ekologické újmy z toho důvodu, že žalovaný vykácel stromy, které byly původně na pozemku ve vlastnictví žalobce. Nárok na náhradu ekologické újmy byl vznesen proto, že dle žalobce nebylo možné v případě pokácených stromů vycházet pouze $\mathrm{z}$ hodnoty vytěženého dřeva, nýbrž bylo zapotřebí zohlednit i ekologickou hodnotu stromů, jejichž pokácením tedy mělo dojít k ekologické újmě.

Tento nárok u soudů neuspěl s ohledem na $\$ 27$ odst. 3 zákona o životním prostředí, podle nějž je oprávněným ze způsobené ekologické újmy pouze stát. Bylo by však možné uvažovat o odlišném postupu žalobce, který mohl hodnotu pokácených stromů (vyšší než pouhá cena jejich dřevní hmoty) dovozovat nikoli z významu těchto stromů pro životní prostředí, nýbrž z jejich významu pro sebe sama. Dle této argumentační linie by pokácení stromů, $\mathrm{k}$ nimž mohl mít žalobce ostatně subjektivní vztah, bylo možné chápat jako narušení jeho osobnostních práv. Domnívám se, že díky novému občanskému zákoníku, který mezi chráněná osobnostní práva zahrnul i právo na př́znivé životní prostředí, by tato argumentace nemusela být tolik komplikovaná a šroubovaná, jako kdyby se uvažovalo pouze o dopadech na jiné aspekty žalobcovy osobnosti, jako např. zdraví, soukromí či důstojnost.

Připomenout lze i př́pad řešený Evropským soudem pro lidská práva ve věci Kyrtatos. ${ }^{21}$ Štrasburský soud se v něm potýkal s tvrzením stěžovatelů, že jejich právo na soukromý a rodinný život dle čl. 8 Úmluvy o ochraně lidských práv a základních svobod bylo porušeno poškozením močálu na ostrově Tinos jakožto cenného přírodního stanoviště. Tento návrh však byl odmítnut, nebot' soud se nemohl ztotožnit s tím, že „narušení života živočichů v mokřadu je útokem na soukromý nebo rodinnýživot žadatelư“. Porušení předmětného ustanovení úmluvy mohou založit pouze škodlivé účinky v soukromé nebo rodinné sféře osob, nikoli obecné poškozování životního prostředí. Evropský soud pro lidská práva ale na druhou stranu naznačil, že by mohly existovat př́pady, kdy by tomu mohlo být jinak. Jednalo by se např́klad o situaci, kdy by poškození životního prostředí spočívalo ve zničení lesa v blízkosti žadatelova obydlí, tedy stav, který by se mohl prímo dotknout stěžovatelova vlastního života.

$\mathrm{Na}$ druhou stranu je třeba připustit, že možnosti př́mého uplatnění tohoto práva $\mathrm{v}$ praxi mohou být značně omezené, protože $\mathrm{v}$ př́padném sporu by toto právo stálo proti vlastnické svobodě nakládat se svým majetkem, přičemž začasté by toto nakládání mohlo být $\mathrm{v}$ souladu s veřejným právem ochrany životního prostředí, resp. dokonce aprobováno př́islušným povolením. Otázka vztahu soukromého a veřejného práva je nepoměrně komplikovanější, než by se mohlo jevit na základě deklarace obsažené ve druhé větě $§ 1$ odst. 1 občanského zákoníku, podle níž je uplatňování soukromého práva

19 MÜLLEROVÁ, H. Právo žít v př́iznivém životním prostředí jako nová součást ochrany osobnosti. Acta Universitatis Carolinae Iuridica, 2017, č. 3, s. 25.

20 Rozsudek Nejvyššího soudu ze dne 30. března 2016 spis. zn. 25 Cdo 2466/2014.

21 Rozsudek Evropského soudu pro lidská práva ve věci Kyrtatos proti Řecku z 22. května 2003, č. stížnosti $41666 / 98$. 
nezávislé na uplatňování práva veřejného. Inspiraci, jakými cestami by se mohl ubírat zákonodárce př̀i snaze o zpřesnění právní úpravy a především soudce při rozhodování o žalobách opírajících se o právo žít v příznivém životním prostředí, by mohla nabízet řešení $\mathrm{v}$ oblasti ochrany před imisemi $\mathrm{v}$ rámci sousedského práva. ${ }^{22}$

Vedle samotného obsahu práva žít $\mathrm{v}$ příznivém životním prostředí vyvolává otázky též mechanismus jeho uplatňování v praxi. Občanský zákoník nabízí k ochraně osobnostních práv zdržovací (negatorní) a odstraňovací (restituční) nároky, které jsou doplněny obecnou úpravou náhrady újmy. ${ }^{23} \mathrm{U}$ obou výše popsaných žalob se mohou v aplikační praxi snadno projevit úskalí spojená s nepřímou ochranou životního prostředí. $Z$ povahy a účelu žalob, resp. jimi prosazovaných nárokủ totiž vyplývá i rozsah opatření, která mohou být požadována a následně soudem v rozsudku nařízena. Pokračování ve škodlivé činnosti tak lze zakázat pouze v rozsahu nezbytném $\mathrm{k}$ ochraně dotčeného osobnostního práva, a to pouze konkrétního žalobce. U odstraňovacího nároku by situace byla ještě komplikovanější, nebot' zde půjde nejen o nalezení vhodného rozsahu restituce, ale i o způsob jejího uskutečnění, aby vůbec byla realizovatelná. Jak zdraví, tak životní prostředí (v príípadě, že bude žalováno porušení samotného práva žít $\mathrm{v}$ př́żnivém životním prostředí) jsou velmi citlivé a v př́ípadě narušení lze následky obtížně vrátit zpět.

Podle § 2894 občanského zákoníku je vždy nahrazována újma na jmění, tedy škoda, zatímco nemajetková újma pouze tehdy, bylo-li tak ujednáno a především tehdy, stanoví-li tak speciálně zákon. Občanský zákoník tak stanoví pouze v několika případech, z nichž nejvýznamnější je újma na přirozených právech člověk, a tedy potenciálně i na právu na život $\mathrm{v}$ př́iznivém životním prostředí. Nemajetková újma na právu žít $\mathrm{v}$ příznivém životním prostředí by mohla být styčným bodem s pojmem ekologické újmy, pokud by za zásah do předmětného osobnostního práva bylo považováno např́ílad narušení krajiny, v níž dotyčný člověk žije, či místního ekosystému. Určení rozsahu takové újmy by však nebylo snadné. ${ }^{24}$

Lze tedy shrnout, že pokud již právo žít $\mathrm{v}$ příznivém životním prostředí bylo do textu občanského zákoníku zařazeno, bylo by žádoucí jeho potenciál pro účely ochrany životního prostředí co nejvíce využít. ${ }^{25}$ Jak však vyplývá i z výše uvedeného, pouhá zmínka v soukromoprávním kodexu je pro praktickou aplikaci poměrně nedostatečná, protože právo žít v příznivém životním prostředí se od běžných osobnostních práv v mnoha směrech odlišuje. Domnívám se, že tento nový institut by si tedy zasloužil podrobnější právní úpravu, která by blíže konkretizovala jeho obsah, jasně vymezila vztah k ve-

22 Viz zejména kapitola 3.2.

23 Viz $§ 82$ odst. 1 občanského zákoníku, kde jsou upraveny oba prvně zmíněné nároky, zatímco nárok na náhradu způsobené újmy vyplývá z pasáže občanského zákoníku upravující závazky z deliktů.

24 Např́klad O. Vícha v této souvislosti připomíná ,značnou obtížnost výpočtu ekologické újmy, a to z toho důvodu, že se jedná o imateriální ztrátu“ - srov. VÍCHA, O. Princip „znečištovatel plati“ “ z právního pohledu. Praha: Linde, 2014, s. 138.

25 Ostatně jak uvádí H. Müllerová, „všude tam, kde zákonná ustanovení dávaji $k$ tomu prostor, je třeba apelovat na takovou interpretaci, která umožni využít ochranu tohoto osobnostního práva ve prospěch ochrany životního prostředí, resp. ho vi̊bec aplikovat, protože lze očekávat, že toto ustanovení jistě nebylo zamýšleno jako ,prázdné c či v praxi nevyužitelné - viz MÜLLEROVÁ, H. Právo žít v příznivém životním prostředí jako nová součást ochrany osobnosti. Acta Universitatis Carolinae Iuridica, 2017, č. 3, s. 32. 
řejnému právu a nastínila i postup uplatňování odstraňovacího nároku či nahrazování nemajetkové újmy.

\section{SOUSEDSKÉ PRÁVO}

Sousedské právo „tvoři souhrn občanskoprávních norem upravujicích vztahy vlastnika a třetích osob při uživání věci, pokud jde o účinky uživání věci na tyto osoby (jejich majetek)“. ${ }^{26}$ Jedná se tedy o typický institut ochrany vlastnického práva, nabízí však - především pak ochrana proti imisím - řadu možností, jak jej použít k vyšším cílům, jako je ochrana životního prostředí. Sousedské právo zahrnuje více témat, přičemž z hlediska využitelnosti k ochraně životního prostředí se jeví relevantní především právní úprava ochrany před zásahy do vlastnického práva, pro něž právnický jazyk používá pojem imise.

K využitelnosti této právní úpravy přispívá už samotná skutečnost, že pojem sousedství je interpretován velmi široce a není omezen na nejbližší sousedy, kteří s původcem imisí sdílí hranici pozemků. ${ }^{27}$ Nemusí se tedy jednat o pouhé ryze sousedské kauzy, nýbrž i př́ípady rozsáhlejších dopadů, jako je hluková zátěž nebo zhoršená kvalita ovzduší ve větší lokalitě, tedy témat již environmentální povahy. Za významnou považuji i skutečnost, že okruh aktivně legitimovaných osob není omezen pouze na osoby fyzické, nebot' se zvyšuje šance na vhodné uplatnění příslušných právních nástrojů. Imisemi totiž může být zjevně ovlivněno užívání majetku i ze strany právnických osob, přičemž lze zmínit, že byla uznána aktivní žalobní legitimace společenství vlastníků jednotek ${ }^{28}$ či územních samosprávných celků. ${ }^{29}$ Vzhledem k tomu, že nový občanský zákoník již nehovoří o obtěžování ${ }^{30}$ a přikazuje vlastníkovi zdržet se všeho, kvůli čemuž by imise vnikaly na sousední pozemek, bylo by možné bez dalšího uzavřít, že ochrana proti imisím je právnickým osobám poskytována rovnocenně jako osobám fyzickým.

Klíčový pojem imise zahrnuje všechny projevy či účinky jednání vlastníka, které mohou pronikat na pozemek jeho souseda. ${ }^{31}$ Imise lze dělit na př́mé a neprrímé (podle toho, zda jsou přímo přiváděny na pozemek jiného vlastníka, což ale $\S 1013$ občanského

26 SPÁČIL, J. In: SPÁČIL, J. a kol. Občanský zákonik III. Věcná práva (\$ 976-1474). Komentář. Praha: C. H. Beck, 2013, s. 146.

27 Např́klad podle J. Spáčila ,sousedství neexistuje jako nějaký zvláštní vztah vzniklý už tím faktem, že určité nemovitosti spolu sousedi; jde pouze o určitou situaci ( $t$. faktický, existující stav), z jejiž povahy vyplývá, že sousedé maji fakticky více přiležitostí, aby se mezi sebou dostávali do právních konfliktů, v jejichž rámci docházi k porušováni, omezování nebo ohrožování jejich práv“ - srov. SPÁČIL, J. - HRABÁNEK, D. Sousedská práva podle nového občanského zákoníku. Praha: Leges, 2015, s. 17.

28 V rámci kauzy pražské magistrály (bude blíže diskutována dále).

29 Rozsudek Nejvyššího soudu ze dne 25. srpna 1999 spis. zn. 2 Cdon 330/97, v němž zaznělo, že pokud „občané [obce] maji schopnost vnímat uvedené imise a jsou-li jimi rušeni při oprávněném uživání nemovitosti ve vlastnictvi obce, je jimi při výkonu svého vlastnického práva rušena i obec".

30 Zákon č. 40/1964 Sb., občanský zákoník (dále též jen „starý občanský zákoník“) ve svém § 127, který upravoval ochranu před imisemi, přikazoval vlastníkovi věci zdržet se všeho, čím by nad míru přiměřenou poměrům obtěžoval jiného nebo čím by vážně ohrožoval výkon jeho práv, zejména nad míru přiměřenou poměrům obtěžovat sousedy.

31 Tím se liší od významu, v němž je tento pojem používán ekologii, resp. ve veřejném právu životního prostředí, viz např. např. na § 2 písm. d) zákona č. 201/2012 Sb., o ochraně ovzduší. 
zákoníku zakazuje, nebo zda se jedná o „takové vlastnické úkony, jejichž bezprostřední účinky jeví se na vlastním pozemku a jež jedině z jiných př́čin mimo vůli vlastníka a bez jeho prispěni pưsobí i na pozemek sousedův"32) nebo na materiální a imateriální (přičemž za hmotné se považují i různé fyzikální jevy, a tedy tento pojem zahrnuje celou škálu uvedenou v demonstrativním výčtu v § 1013 občanského zákoníku, tedy odpad, vodu, kouř, prach, plyn, pach, světlo, stín, hluk, otřesy a jiné podobné účinky). Ve vztahu $\mathrm{k}$ životnímu prostředí jsou přitom relevantní především hluk a znečištění šířené vzduchem či vodou.

V souvislosti $\mathrm{s}$ ochranou proti imisím poskytovanou v rámci sousedského práva považuji za zásadní následující otázky, resp. problémové okruhy:

\subsection{URČENÍ MÍRY PŘIMĚŘENÉ MÍSTNÍM POMĚRŮM}

Klíčovým pojmem § 1013 odst. 1 občanského zákoníku, který slouží k rozlišení, zda se lze určitým imisím bránit (požadovat, aby se jejich původce zdržel dalš́ího rušení) či zda nezbývá než imise strpět, je, zda překračují míru přiměřenou místním poměrům. Bohužel literatura ani judikatura nejsou stran výkladu tohoto pojmu konzistentní, obecně lze alespoň shrnout, že místní poměry, resp. míra jim přiměřená, jsou záležitostí individuální lišící se místo od místa podle lokálních podmínek. ${ }^{33}$

Nejvyšší soud se k této problematice vyjádřil např. ve svém rozhodnutí ve věci rušení zejména hudebními produkcemi ve večerních a nočních hodinách, přičemž uvedl, že „soud rozhodujicí o návrhu na ochranu podle uvedeného ustanovení se nemůže omezit jen na konstatování, že namitaný zásah je v souladu se stavem v mistě obvyklým, ale musí vždy zohlednit míru přiměřenou poměrům (které by měly být)“. Dovodil totiž, že „,pokud by se totiž hranice mezi prípustným a neprípustným obtěžováním měla určovat jen podle poměrů v daném mistě a čase a ne podle poměrü, které jsou žádouci a které by měly přetrvávat, nebylo by možné domáhat se úspěšně ochrany podle § 127 odst. 1 ObčZ $v$ prípadě, že i chováni všech ostatních fyzických nebo právnických osob v mistě je z hlediska tohoto ustanovení závadné“" 34

Je zajímavé, že o pět let později stejný senát Nejvyššího soudu tento postoj poněkud zmírnil, když v př́padu jiného rušení zejména hudbymilovnými sousedy zhodnotil, že je „třeba vzít v úvahu mistni poměry, intenzitu hluku a to, zda jde o rušení jednorázové, opakované nebo úmyslné. Teprve v prípadě, že by se intenzita obtěžování hlukem v dané

32 SEDLÁČEK, J. In: SEDLÁČEK, J. - SPÁČIL, J. Vlastnické právo. Praha: Wolters Kluwer ČR, 2012, s. 91. O několik stran dále (na s. 98) pak týž autor dokonce píše, že ,,́činek se nejeví jako pokračování činnosti, ale jako stav prostředí, který byl činností vlastnikovou sice zpuisoben, ale nepatři již k jeho uživání véci“".

33 V této souvislosti lze pro odlehčení zmínit, že okresní soud v Benešově ve svém prvoinstančním rozhodnutí ve věci obtěžování zápachem z hnojiště připomněl, že „,míra tolerance $k$ zápachu z chlévské mrvy na venkově je větší než ve městě - citováno dle rozsudku Nejvyššího soudu ze dne 29. března 2017 spis. zn. 22 Cdo 4847/2016.

34 Rozsudek Nejvyššího soudu ze dne 26. dubna 2006 spis. zn. 22 Cdo 223/2005. S ohledem na podobnost úpravy ochrany před imisemi ve starém i novém občanském zákoníku dospěl i Nejvyšší osud k závěru, že dosavadní judikatura je v zásadě i nadále použitelná - viz rozsudek Nejvyššího soudu ze dne 29. dubna 2015 spis. zn. 22 Cdo 3940/2014. 
lokalitě zjevnè vymykala stavu v jiných obdobných lokalitách, bylo by třeba při posuzování žaloby přihlédnout i k obvyklým poměrům v takových lokalitách."35

V obou výše popsaných kauzách byla ochrana na základě sousedské negatorní žaloby poskytnuta, lze však nalézt i př́ípady, kdy místní poměry převážily. Příkladem může být rozhodnutí ve věci alergika požadujícího po včelaři odstranění jeho včelstev, v němž byl žalobce poučen, že žije v lokalitě intenzivního včelaření a tedy hojného výskytu včel „a podle této situace musí své chování a způsob života uzpůsobit“. ${ }^{36}$

S vymezením místních poměrů úzce souvisí i další pojem použitý v textu § 1013 odst. 1 občanského zákoníku, tedy obvyklé užívání pozemku. To by totiž nemělo být imisemi podstatně omezováno, jinak bude mít jejich původce povinnost se takové rušivé činnosti zdržet. Nejvyšší soud se při úvaze, jaký okruh pozemků lze zahrnout v daném př́ípadě pod pojem obvyklého užívání, dospěl k závěru, že ,nelze zcela srovnávat poměry v obytné ćásti průmyslového města, jehož továrny přmo či nepř́mo zajišstují zaměstnáni pro významnou část obyvatel, s poměry v obci, zaměrené na turistiku a rekreaci, $i$ když v obou těchto př́padech jde o uživáni obytných domư “" ${ }^{37}$ Pokud jde o určení, zda je obvyklé užívání pozemku omezeno podstatně, nabízí J. Spáčil vodítko v podobě vývoje ceny imisí zasažené nemovitosti, nebot' její pokles by totiž mohl omezení využitelnosti pozemku dokládat. ${ }^{38}$

\subsection{SOULAD S VEŘEJNOPRÁVNÍMI LIMITY}

V dnešní době, kdy je valná část lidských ekonomických aktivit svázána regulací a mnohdy též podmíněna veřejnoprávním povolením, se jako klíčová jeví otázka vztahu veřejného práva, resp. limitů jím stanovených či povolení na jeho základě vydaných ${ }^{39} \mathrm{k}$ soukromoprávní ochraně poskytované sousedským právem.

Nejvyšší soud totiž již za platnosti starého občanského zákoníku judikoval, že ochrana poskytovaná sousedským právem je na ochraně založené na předpisech správního práva nezávislá. Proto bude na jednu stranu platit, že překročení mezí stanovených správněprávní normou bude znamenat překročení přiměřené míry, za opačné situace, kdy budou stanovené veřejnoprávní limity dodrženy, však tento vztah jako samozřejmý platit nebude. Nárok na ochranu před imisí totiž bude dán, i ,pokud v době rozhodování soudu bude imise sice v mezích daných správním předpisem, půjde však nepochybně o obtěžování nad míru přiměrenou poměrưm “. ${ }^{40}$ Do jisté míry precedenční význam tohoto rozhodnutí pak dokládá i jeho použití jako klíčového argumentu v př́ípadu hluku na magistrále. ${ }^{41}$ Taktéž v př́padě Arcelor Mittal ze strany Nejvyššího soudu zaznělo, že „důležitým vodítkem pro posouzeni toho, zda jde o rušení přesahujicí míru přiměřenou

35 Usnesení Nejvyššího soudu ze dne 24. listopadu 2011 spis. zn. 22 Cdo 1578/2010.

36 Rozsudek Krajského soudu v Plzni ze dne 1. ledna 1996 spis. zn. 10 Co 742/95.

37 Rozsudek Nejvyššího soudu ze dne 29. dubna 2015 spis. zn. 22 Cdo 3940/2014.

38 SPÁČIL, J. In: SPÁČIL, J. a kol. Občanský zákoník III. Věcná práva (§ 976-1474). Komentár̆. Praha: C. H. Beck, 2013, s. 149.

39 Např. povolení orgánu ochrany ovzduší podle § 11 zákona o ochraně ovzduší.

40 Usnesení Nejvyšš́ího soudu ze dne 27. dubna 2010 spis. zn. 22 Cdo 1296/2008.

41 Viz rozsudek Nejvyššího soudu ze dne 24. listopadu 2010 spis. zn. 22 Cdo 3281/2008. Tato kauza bude diskutována níže. 
poměrům (nyní viz i § 1013 odst. 1 o. z.), je zjištěni, že rušení presahuje limity uvedené ve veřejnoprávnich predpisech".42

Pokud se jedná o opačnou situaci, tedy když veřejnoprávní limit není překročen, Nejvyšší soud vynesl rozsudek, v němž konstatoval, že nepřekročení limitu sice neznamená, že „lze vycházet primárně z předpokladu, že při dodržování veřejnoprávnich norem zpravidla nepưjde ani o nepř́pustnou imisi v režimu $\$ 1013$ odst. 1 o. z."“.43 Že však situace není zdaleka tak jednoznačná, dokládají i soudní rozhodnutí, z nichž vyplývá možnost odlišného př́stupu. Nejvyšší soud například uvedl, že „v konkrétním prípadě sice obtěžování imisemi nebylo takové intenzity, že by predstavovalo porušení př́slušných veřejnoprávnich předpisů, ale část obce, ve které k rušení dochází, vždy byla oblastí klidného bydlení... Je tedy třeba zvážit, zda obtěžování žalované hlukem i výfukovými plyny tak převyšuje míru př̀iměřenou mistním poměrüm." “44

Zatímco výše diskutovaná problematika plně navazuje na závěry, které se vytvořily již za platnosti předchozího občanského zákoníku, přinesla rekodifikace českého občanského práva jinou výraznou změnu týkající se právě vztahu soukromoprávní úpravy ochrany před imisemi vưči předpisům veřejného práva, na jejichž základě dochází k posuzování a povolování různých činností, které mohou být zdrojem imisí, když došlo k zavedení institutu tzv. privilegovaných imisí. ${ }^{45}$

Podle $§ 1013$ odst. 2 občanského zákoníku totiž v prŕípadě, že činnost, jež je zdrojem imisí, byla úředně povolena a rozsah imisí toto povolení nepřekračuje, je možné žádat pouze náhradu újmy v penězích, nikoli zdržení se rušení. Ačkoli je tato konstrukce v jistém ideovém rozporu s pojetím nezávislého uplatňování soukromého a veřejného práva vyjádřeným v $§ 1$ odst. 1 občanského zákoníku, představuje na druhou stranu logický krok ve snaze zabránit zjevným vnitřním rozporům v praktickém uplatňování práva různými větvemi veřejné moci. Pokud je valná většina znečištujících a dalších aktivit, jejichž důsledkem mohou být soukromoprávní terminologií imise vnikající na cizí pozemky a rušící práva jiných osob, $v$ současné době veřejnoprávně regulována stanovením určitých limitů a dalších podmínek a povětšinou i vyžaduje př́íslušné povolení, je žádoucí, aby s projevy moci výkonné (činnost správních orgánů) a normotvorné (stanovení limitů $\mathrm{v}$ zákonech a především v prováděcích právních předpisech $\mathrm{k}$ nim vydaných) nekolidovalo rozhodování civilních soudů. Jejich role totiž spočívá v rozhodování konkrétních sporů ohledně individuálních práv v jednotlivých př́ípadech. Původní důvod vzniku tohoto ustanovení vysvětloval F. Rouček odkazem na legislativní myšlen-

42 Rozsudek Nejvyššího soudu ze dne 28. ledna 2015 spis. zn. 22 Cdo 636/2014.

43 Rozsudek Nejvyšśího soudu ze dne 25. října 2017 spis. zn. 22 Cdo 3859/2017.

44 Rozsudek Nejvyššího soudu ze dne 13. srpna 2014 spis. zn. 22 Cdo 2877/2012.

45 Samotný výraz ,privilegované imise“ odkazuje k tomu, že jsou zákonodárcem do určité míry privilegovány zvláštní právní úpravou, která má redukovat možnost jejich zákazu soukromoprávní (uložením povinnosti zdržet se těchto imisí) či že se odvíjí od určitého privilegia uděleného původci imisí v podobě úředního povolení k provozu. 
ku stojící za § 364a ABGB, ${ }^{46}$ „,totižže nákladné investice nemají býti zmařeny“, ${ }^{47}$ nebot’ v praxi může být citlivěji vnímána určitá ekonomická nelogičnost až nespravedlnost než samotná nekonzistentnost různých právních postupů. J. Spáčil s E. Dobrovolnou pak otevřeně konstatují, že „účelem tohoto ustanovení je ochrana průmyslového, resp. živnostenského podnikáni" 48

$\mathrm{Na}$ tomto místě lze zmínit napřr. rozhodnutí Nejvyššího soudu ve věci žaloby na zdržení se rušení hlukem ze skladového areálu, v němž soud rekapituloval podmínky aplikovatelnosti § 1013 odst. 2 občanského zákoníku. Těmi jsou:

1. provoz závodu nebo podobného zařízení byl úředně schválen, přičemž ve schvalovacím procesu byl schvalující orgán povinen zabývat se účinky provozu na okolí (zpravidla životní prostředí). Samotné imise nemusejí být schvalovány, musí být však schválena činnost, produkující imise;

2. imise nesmí ohrožovat základní práva dotčeného souseda, zejména právo na ochranu života a zdraví;

3. žalobce (nebo jeho právní předchůdce) musí mít v řízení o úřední schválení provozu, ze kterého imise pocházejí, postavení účastníka povolovacího řízení, resp. možnost uplatnit námitky proti provozu $-\mathrm{z}$ této podmínky však Nejvyšší soud připustil výjim$\mathrm{ku}$, pokud bude výsledkem z poměřování dotčených práv testem proporcionality. ${ }^{49}$ K tomu Nejvyšší soud doplnil, že negatorní žalobě proti obtěžování privilegovanou imisí by bylo možné vyhovět, půjde-li imisi zabránit „technickým nebo organizačním opatřením, které žalovaného neúměrně nezatiži a lze jej po něm spravedlivě žádat". 50

Při splnění výše analyzovaných podmínek se může projevit ona privilegovanost provozu, resp. imisí jím působených, a oproti běžnému režimu dle § 1013 odst. 1 občanského zákoníku nebude možné uložit původci zdržení se imisí. Zákon nabízí jiné řešení předmětné situace, a to nárok na peněžní náhradu vzniklé újmy. Tato újma může přitom spočívat zejména ve snížení hodnoty nemovité věci, at' již by se jednalo o prosté snížení ceny nebo např. zhoršení úrodnosti zemědělské půdy. ${ }^{51}$

46 Předmětný § 1013 odst. 2 občanského zákoníku je do značné míry návratem dříve platné úpravy z dob Rakouska-Uherska a první republiky, kde byla zařazena v § 364a ABGB (Allgemeines bürgerliches Gesetzbuch für die gesammten deutschen Erbländer der Oesterreichischen Monarchie, JGS Nr. 946/1811), přičemž toto ustanovení i nadále u našich jižních sousedů zůstává v platnosti. Nejvyšší soud dokonce výslovně deklaroval, že s ohledem na návaznost textu § 1013 odst. 2 občanského zákoníku na jeho rakouský vzor ,je tak třeba přihlédnout $k$ výkladu tohoto ustanovení ve starši české právní vědě i judikatuře a také k tomu, jak je vykládáno a aplikováno v Rakousku“ - viz rozsudek Nejvyššího soudu ze dne 29. března 2017 spis. zn. 22 Cdo 4847/2016.

47 ROUČEK, F. In: SCHROTZ, K. - ANDRES, B. - FAJNOR, V. - ZÁTURECKÝ, A. - HARTMANN, A. - ROUČEK, F. - SEDLÁČEK, J. Komentář k československému obecnému zákoníku občanskému a občanské právo platné na Slovensku a v Podkarpatské Rusi. Díl 2 (§§ 285 až 530). Repr. pův. vyd. z r. 1935. Praha: Codex Bohemia, 1998, s. 253.

48 SPÁČIL, J. - DOBROVOLNÁ, E. In: SPÁČIL, J. a kol. Občanský zákoník III. Věcná práva (\$ 976-1474). Komentár̆. Praha: C. H. Beck, 2013, s. 156.

49 Rozsudek Nejvyššího soudu ze dne 20. září 2017 spis. zn. 22 Cdo 3290/2017.

50 Rozsudek Nejvyššího soudu ze dne 29. března 2017 spis. zn. 22 Cdo 4847/2016.

51 SPÁČIL, J. - DOBROVOLNÁ, E. In: SPÁČIL, J. a kol. Občanský zákoník III. Věcná práva (\$ 976-1474). Komentár̆. Praha: C. H. Beck, 2013, s. 160. 


\section{3 ČASOVÉ HLEDISKO - OTÁZKA PŘÍCHODU KE ZDROJI IMISÍ}

Jestliže je míra přiměřená místním poměrům záležitostí podmíněnou místními a individuálními okolnostmi, nabízí se otázka, zda by mohl znečišt’ovatel lokalitu, v níž působí a kterou zatěžuje působenými imisemi, právě z imisního hlediska ovlivnit natolik, že každý nově příchozí subjekt se bude muset této situaci přizpůsobit. Možnosti jeho obrany proti imisím by byly vyloučeny argumentem, že se vědomě přistěhoval ke zdroji imisí, a tedy se s nimi implicitně smírili. ${ }^{52}$

Tento názor zazněl například v rozsudku Evropského soudu pro lidská práva ve věci Zammit Maempel, v němž bylo odmítnuto, že by ohňostroje pořádané na Maltě mohly být s ohledem na řídkou frekvenci porušením práva na respektování soukromého a rodinného života a obydlí. Soud ale především poznamenal, že ,žadatelé ziskali predmětný majetek vědomi si situace, na niž si nyni stěžují. Navzdory tomu, že je predchozí vlastníci informovali o své zkušenosti, žadatelé pokračovali v nabytí daného majetku a udělali z něj svioj domov. Soud považuje, stejně jako předtím domácí soudy, že toto je závažný faktor při zvažování relevantních okolností, bez ohledu na to, že byli z právního hlediska oprávněni tam žit. "53

Lze též zmínit argumentaci Ústavního soudu v rámci jeho rozhodování v případu hluku na pražské magistrále. Ohledně stavu předmětné komunikace totiž konstatoval, že ,je výsledkem mnohaletého vývoje, který mohl být mnohým z vedlejších účastniků znám již v době nabytí jejich vlastnického práva“. 54 Ústavní soud tím zdůvodňuje svůj názor, že obecné soudy při poměřování ochrany vlastnických práv osob postižených obtěžováním imisemi a žalovaného vlastníka předmětné pozemní komunikace (kterým je hlavní město Praha) neodůvodněně upřednostnily práva žalobců. Proto ji lze dle mého mínění rozumět i v tom smyslu, že Ústavní soud považuje př́ichod (přistěhování se, pořízení nemovitosti) do již problémové oblasti za smíření se s obtěžováním, což otupuje nárok na ochranu před takovými imisemi.

Obdobný argument Ústavní soud uplatnil i ve svém nálezu vydaném ve věci žaloby podané proti obci Vysoká Srbská týkající se obtěžování provozem na účelové komunikaci, když uvedl, že ,předmětná komunikace historicky (již od 19. století) nejen, že zajištuje dopravní obslužnost k přilehlým nemovitostem, ale slouži i jako př́jezdová cesta do přilehlých lesì, a tedy i ke svozu vytěženého dřeva, tj. dávno předtím, než vedlejši účastnice ř́zení nabyla predmětnou nemovitost do svého vlastnictvi".55

Taktéž Nejvyšší soud ve věci hluku ze stadionu olomouckého fotbalového klubu použil podobnou úvahu, nebot' v jeho rozsudku zaznělo, že ,dovolatelé si tedy vzhledem k blizkosti sportoviště mohli být vědomi toho, v jaké lokalitě se jejich rodinný dưm

\footnotetext{
52 V systému common law je tato problematika známa jako „coming to the nuisance“, což je označení okolnosti vylučující protiprávnost v případě, že žalobce stěžující si na rušení či obtěžování již přišel (přistěhoval se) do lokality takto zatížené. Je však pravdou, že tento důvod není jako okolnost vylučující protiprávnost př́liš uznáván.

53 Rozsudek Evropského soudu pro lidská práva ve věci Zammit Maempel proti Maltě z 22. listopadu 2011, č. stížnosti 24202/10.

54 Nález Ústavního soudu ze dne 11. ledna 2012 spis. zn. I. ÚS 451/11.

55 Nález Ústavního soudu ze dne 4. února 2016 spis. zn. II. ÚS 2144/14.
} 
nachází, a že v průběhu času může dojit k nárůstu imisi", což je třeba zohlednit v úvaze, zda dochází k obtěžování nad míru přiměřenou poměrům. ${ }^{56}$

\subsection{HLUK PŮSOBENÝ PROVOZEM NA POZEMNÍCH KOMUNIKACÍCH}

Ze sousedských sporů ohledně rušení imisemi, které mají relevanci z hlediska ochrany životního prostředí, se nejčastěji řeší problematika hluku působeného provozem na pozemních komunikacích.

Základním problémem české právní úpravy vlastnictví dopravních komunikací je skutečnost, že pozice vlastníka zakládá zcela minimální možnost ovlivňovat provoz, který se na komunikaci odehrává. Pro všechny pozemní komunikace (dálnice, silnice a místní komunikace stejně jako pro veřejné účelové komunikace) totiž platí, že jsou předmětem obecného užívání, přičemž jeho regulaci má v působnosti silniční správní úřad. Proto též zákon o pozemních komunikacích ${ }^{57}$ ve svém $§ 27$ odst. 4 vylučuje odpovědnost vlastníka pozemní komunikace za škody vzniklé vlastníkům sousedních nemovitostí v důsledku provozu na nich. Tuto skutečnost potvrdil i Ústavní soud, který dospěl k závěru, že ,vzhledem $k$ tomu, že obec nevyvíjí a ze zákona nemůže vyvíjet žádnou činnost, kterou lze ovlivnit provoz na pozemni komunikaci, je pojmově vyloučeno, aby jí byla uložena povinnost zdržet se rušení hlukem pocházejícím z provozu na pozemni komunikaci“. 58

Nejznámější je v tomto směru případ žaloby podané obyvateli bydlícími v blízkosti pražské ulice 5. května, která je úsekem tzv. pražské magistrály. V této kauze se střetly i názory obecného civilního soudnictví vyjádřené především v rozhodnutí Nejvyššího soudu, který upřednostňoval ochranu individuálních práv před rušením hlukem, s Ústavním soudem, jenž naopak nastolil otázku proporcionality při ochraně vlastnických práv, která právě ve vztahu k provozu na pozemních komunikacích nabývá na významu, nebot' vlastník nemovitosti, z níž rušivé vlivy pocházejí (v dané věci obec), nemá z důvodu obecného uživání pozemní komunikace náležité prostředky, jak využívání této své nemovitosti regulovat. ${ }^{59}$

Pozoruhodné na této kauze je to, že Nejvyšší soud se nesmíril se závěry Ústavního soudu a v rámci dalšího pokračování předmětné kauzy, stejně jako v některých podobných př́ípadech, které následovaly, se snažil nalézt prostor, v němž by mohl nadále pro-

56 Rozsudek Nejvyššího soudu ze dne 25. března 2015 spis. zn. 22 Cdo 2270/2012.

57 Zákon č. 13/1997 Sb., o pozemních komunikacích.

58 Nález Ústavního soudu ze dne 11. ledna 2012 spis. zn. I. ÚS 451/11.

59 Prvoinstanční rozsudek byl vynesen dne 17. dubna 2007 pod spis. zn. 13 C 251/2006. V něm Obvodní soud pro Prahu 1 sice konstatoval, že práva žalobců byla ohrožena, avšak z důvodu zdlouhavosti a nákladnosti nápravy a problematický výkon př́padného rozhodnutí žalobu zamítl. S tímto závěrem se odvolací soud, tedy Městský soud v Praze, neztotožnil a v rozsudku spis. zn. 54 Co 390/2007 ze dne 30. ledna 2008 naopak uložil hlavnímu městu Praha zdržet se rušení, přičemž mu poskytl na provedení potřebných opatření lhůtu jednoho roku. S tímto rozsudkem se však Praha nesmírila a podala dovolání k Nejvyššímu soudu, který jej však rozsudkem spis. zn. 22 Cdo 3281/2010 ze dne 24. listopadu 2010 zamítl. Zlom však přinesla ústavní stížnost, kterou podalo hlavní město Praha. Té Ústavní soud nálezem spis. zn. I. ÚS 451/11 ze dne 11. ledna 2012 vyhověl z důvodu, že předchozími rozhodnutími Nejvyššího soudu a Městského osudu v Praze bylo porušeno právo na ochranu majetku podle čl. 11 odst. 1 Listiny základních práv a svobod (usnesení předsednictva České národní rady č. 2/1993 Sb., o vyhlášení Listiny základních práv a svobod jako součásti ústavního pořádku České republiky), a proto zmíněné dva rozsudky zrušil. 
sazovat svůj náhled na danou problematiku, který je vůči osobám postiženým důsledky silničního provozu vstř́icnější. ${ }^{60}$ Nejvyšší soud zašel ve svém výkladu př́islušného nálezu Ústavního soudu až ke konstatování, že „odepřit ochranu proti nadměrným imisím lze pouze za předpokladu, že k porušování práv žalobců nedocházi v míre nepřiměrené dlouhodobě se formujicím poměruim v okoli veřejné komunikace. Jenom v takovém připadě není možné uložit žalovanému povinnost zdržet se rušení hlukem a imisemi škodlivin pocházejícími z provozu na pozemní komunikaci.“61

Výměna právních názorů mezi Nejvyšším a Ústavním soudem k problematice imisí vyvolaných silniční dopravou na komunikacích ve vlastnictví obce proběhla i v případu obce Vysoká Srbská, která byla žalována kvůli poškozování statiky stavby ve vlastnictví žalobkyně v důsledku provozu těžkých nákladních vozidel po blízké pozemní komunikaci. Nejvyšší soud zde rozhodl (v návaznosti na předchozí rozsudky soudů nižších instancí, které uložily obci povinnost zabránit imisím), že nález Ústavního soudu ve věci pražské magistrály ,,nelze na danou věc aplikovat, nebot’ tam šlo o jiný skutkový (nešlo o př́mé ohrožení vlastnického práva) i právni (nešlo o účelovou komunikaci) stav".62 Ústavní soud opět tento př́stup odmítl a v návaznosti na zrušení rozhodnutí vzešlých z obecného soudnictví uložil soudům, znovu posoudit míru ochrany poskytnuté vlastnickému právu žalobkyně, a to nejen z hlediska intenzity zásahu do tohoto vlastnického práva, ale zejména z hlediska existence odpovědnosti stěžovatelky při realizaci jejího vlastnického práva k predmětné účelové komunikaci, ... a v neposlední řadé i možnostech, jak onomu ,ohrožujicímu'stavu vi̊bec zabránit". ${ }^{63}$

Vzhledem k tomu, že ani původní kauza pražské magistrály (s prvním soudním rozhodnutím vyneseným již v roce 2007) není definitivě završena a v mezidobí přibyly podobné př́ípady nové (např̀. probíhá spor ve věci hlukových imisí z magistrály v ulici v Holešovičkách ${ }^{64}$ ), nelze $v$ tuto chvíli činit definitivní závěry. Přestože řada soudních rozhodnutí nevyznívá př́znivě pro žalobce a přeneseně ani pro věc ochrany životního prostředí v podobě snižování zátěže působené silniční dopravou, stále dle mého mínění přetrvává naděje, že soudy při rozhodování těchto nesporně velmi složitých kauz budou přihlížet i k environmentálním dopadům a budou poskytovat ochranu lidem nadměrně trpícím negativními důsledky provozu na pozemních komunikacích.

60 Rozsudek Nejvyššího soudu ze dne 7. února 2017 spis. zn. 22 Cdo 1313/2016, v němž Nejvyšší soud dovodil, že z předmětného nálezu nevyplývá, že ,by, bez dalšího ‘ bylo vyloučeno uložit obci povinnost zdržet se rušeni hlukem pocházejícím z provozu na pozemnich komunikacích".

61 Ve svém rozsudku ze dne 3. června 2015 spis. zn. 22 Cdo 3277/2014 Nejvyšší soud dokonce Ústavnímu soudu vytknul, že ,,v citovaném nálezu [spis. zn. I. ÚS 451/11] neuvedl, jak mají osoby, rušené nadmérným hlukem z pozemni komunikace, postupovat, chtěji-li se proti obtěžováni bránit; z jeho nálezu však nelze ani dovodit, že by , bez dalšího 'bylo vyloučeno uložit obci povinnost zdržet se rušení hlukem pocházejicím z provozu na pozemních komunikacich; to plati i pro jiné územni samosprávné celky".

62 Usnesení Nejvyššího soudu ze dne 26. března 201422 spis. zn. Cdo 843/2013.

63 Nález Ústavního soudu ze dne 4. února 2016 spis. zn. II. ÚS 2144/14.

64 Jedná se o další z vlekoucích se kauz, nebot' první prvoinstanční rozhodnutí bylo vyneseno již dne 6. záŕí 2011 (ale jak dokládá spisová značka, případ je ještě starší). Z aktuální doby lze zmínit, že prvoinstanční soud (obvodní soud pro Prahu 1), po dvou svých předchozích rozsudcích, v nichž žalobcủm vyhověl a uložil hlavnímu městu Praze snížit úroveň hluku, a které byly zrušeny na základě opravných prostředků, rozhodl ve prospěch žalovaného - viz POKORNÝ, M. Jinde jsou na tom hůr̆, řekl soud a zamítl žalobu na hluk a emise v pražských Holešovičkách. Ihned.cz [online], 10. 10. 2019 [cit. 13. 12. 2019]. Dostupné z: https://domaci.ihned.cz/c1-66657410-jinde-jsou-na-tom-hur-rekl-soud-a-zamitl-zalobu-na-hluk-a-emise -v-prazskych-holesovickach. 
Proto (a částečně i přesto) se domnívám, že i nadále by tato problematika ve své soukromoprávní dimenzi měla být ponechána převážně na soudní judikatuře, tedy neshledávám př́liš možností, kterými by zákonodárce mohl vstoupit do relevantních ustanovení občanského zákoníku způsobem, který by ve výsledku nebyl přehnaný či jinak kontraproduktivní.

\section{ODPOVĚDNOST ZA ŠKODU}

Jednou ze základních zásad soukromého práva, a jistě by bylo možné tvrdit, že i etických zásad prostého mezilidského soužití, je nepoškozovat svým jednáním druhé lidi. $\mathrm{V}$ platném právu se tato zásada odráží v povinnosti předcházet újmě (nemajetkové i na jmění) a v povinnosti újmu, ke které i přsesto dojde, postižené osobě nahradit. $\mathrm{V}$ této souvislosti je třeba připomenout, že cestou soukromého práva lze požadovat kompenzaci pouze určité části ztrát, které na životním prostředí vznikly, ${ }^{65}$ přičemž lze citovat I. Průchovou, že ,škodami na životním prostředí bude třeba rozumět v oboru soukromého práva újmy na, vlastnitelných 'složkách životního prostředi" ${ }^{\prime \prime}{ }^{66}$

Podobně jako v předchozích dvou tématech, kterým se věnuje toto pojednání, i v príípadě odpovědnosti za škodu je pro praxi velice důležitá otázka vztahu $\mathrm{k}$ veřejnému právu. To nejen stanoví limity př́ípustného, resp. nepř́ípustného ohrožování a poškozování životního prostředí, ${ }^{67}$ upravuje ale též specifické nástroje předcházení a nápravy ekologické újmy. V tomto směru je třeba připomenout především $\S 21$ odst. 6 zákona o předcházení ekologické újmě a o její nápravě, ${ }^{68}$ který vylučuje postup podle obecných předpisů o odpovědnosti za škodu (tedy podle občanského zákoníku), pokud byla postupem podle zmíněného zákona uhrazena i škoda na majetku. Účel i postup uplatnění obou mechanismů je velmi odlišný, problém by však v př́ípadě jejich souběžného uplatnění mohl spočívat $\mathrm{v}$ tom, jak by civilní soud rozhodující o žalobě na náhradu škody podle občanského zákoníku posuzoval míru uhrazení majetkové škody (přičemž už jen určení její výše bývá $\mathrm{v}$ environmentálních kauzách nesnadné) v rámci nápravy ekologické újmy. Domnívám se, že citované ustanovení nelze pojímat paušálně a např́klad požadovat náhradu zisku ušlého do doby nápravy ekologické újmy (a hypoteticky tedy i náhradě skutečné škody) by poškozenému neměla být upřena. Komplikace mohou nastat i z procesního hlediska, pokud by oba postupy byly aplikovány paralelně. Civilnímu soudu by se však podle mého názoru nabízelo pojímat postup podle zákona o předcházení ekologické újmě a o její nápravě jako předběžnou otázku a z tohoto důvodu přerušit řízení. ${ }^{69} \mathrm{~V}$ této souvislosti nelze opomenout ani $\S 27$ zákona o životním

65 Pojem ztráty na životním prostředí představuje společné označení pro ,škodu (ekonomickou, materiálni) na těch složkách životniho prostředí, které jsou v právním slova smyslu věcmi, tak i pro ekologickou újmu (imateriálni sniženi funkčních vlastností ekosystémů či jiných hodnot prostředi)“" - viz DAMOHORSKÝ, M. a kol. Právo životního prostředí. 3. vyd. Praha: C. H. Beck, 2010, s. 81.

66 PRƯCHOVÁ, I. In: JANČÁŘOVÁ, I. - PEKÁREK, M. - PRŮCHOVÁ, I. Odpovědnost v právu životního prostředi - současný stav a perspektivy. Brno: Masarykova univerzita, 2013, s. 189.

67 Viz čl. 11 odst. 3 a čl. 35 odst. 3 Listiny základních práv a svobod.

68 Zákon č. 167/2008 Sb., o předcházení ekologické újmě a o její nápravě a o změně některých zákonů.

69 Viz § 109 odst. 2 písm. b) zákona č. 99/1963 Sb., občanský soudní řád. 
prostředí, který (ve svém odstavci 4) v režimu nápravy ekologické újmy subsidiárně využívá obecné předpisy o odpovědnosti za škodu a o náhradě škody, byt' je toto řešení předmětem kritiky. ${ }^{70}$

Pokud jde o význam náhrady škody jakožto majetkové újmy z hlediska životního prostředí, domnívám se, že je třeba rozlišovat dvě situace, resp. dvě roviny. Bude záležet na tom, zda dochází ke škodě na oněch vlastněných součástech životního prostředí (například les) nebo zda škoda vzniká na „obyčejných věcech“, avšak jako následek jevů škodlivých pro životní prostředí. Samozřejmě může dojít i k propojení obou dvou rovin, jako je tomu v prŕpadě poškození lesního porostu průmyslovými exhalacemi, které bude diskutováno níže.

Pokud byla poškozena věc s environmentální hodnotou, především složka životního prostředí, bude jistě prioritní její uvedení do stavu co nejvíce se blížícího stavu přirozenému, přírodnímu. V tomto směru jsou jasně patrné limity soukromoprávního přístupu, který je z povahy věci parciální a založený na individuální aktivitě směřující k prosazení zájmů poškozeného, který ne vždy musí mít náležitý ekologický nadhled nad kauzou poškozeného vlastního majetku.

Naopak v případech, kdy dochází k poškození běžných věcí v důsledku znečišt’ování (např. domu vibracemi z nákladní dopravy či zeleninové zahrádky prachem z provozu vyznačujícího se značnou prašností), bude souvislost s ochranou životního prostředí spočívat v něčem jiném. Protože $\mathrm{v}$ dané situaci nebude životní prostředí chráněnou (a poškozenou) hodnotou, bude se pro-environmentální efekt náhrady škody odvíjet od toho, že škůdce (znečišt’ovatel) bude nucen poskytnout náhradu. Tento zásah do jeho majetkové sféry by měl působit de facto téměř sankčním zpo̊sobem se všemi aspekty sankcím přisuzovaným. Z hlediska životního prostředí bude jistě nejdůležitější působení deterenční, tedy s účinky generální i individuální prevence.

Problematika odpovědnosti za škodu zahrnuje v českém občanském právu dvě provázané oblasti, které na sebe věcně navazují, tedy předcházení vzniku újmy a následně, pokud už k ní došlo, i povinnost k jejímu odčinění, přičemž v obou těchto oblastech došlo v rámci rekodifikace ke změnám, které si dle mého mínění zasluhují pozornost.

\subsection{GENERÁLNÍ PREVENCE}

Pravidlo, že je snazší škodě předcházet, než ji následně napravovat, platí v oblasti ochrany životního prostředí snad ještě více než v jiných odvětvích, nebot' složitost a vnitřní provázanost jeho jednotlivých složek a v nich probíhajících jevů komplikují možnost předvídání důsledků negativních zásahů i jejich nápravu.

Z hlediska ochrany životního prostředí je proto skličující, že v novém občanském zákoníku v § 2900 (upravujícím generální prevenci) již nejsou v demonstrativním výčtu chráněných objektů uvedeny př́roda a životní prostředí, jak tomu bylo v $§ 415$ starého občanského zákoníku. ${ }^{71} \mathrm{Na}$ druhou stranu je třeba poznamenat, že z pohledu tématu

70 DAMOHORSKÝ, M. a kol. Právo životního prostředí. 3. vyd. Praha: C. H. Beck, 2010, s. 88.

71 V celém starém občanském zákoníku se jednalo o jediný výskyt pojmů životní prostředí a př́roda. Za zmínku stojí, že tyto pojmy figurovaly v ustanovení upravujícím generální prevenci i v dřivější podobě návrhu nového občanského zákoníku. 
tohoto článku nejde o zásadní změnu, pokud ustanovení i nadále pamatuje na prevenci újmy na životě, zdraví a vlastnictví. Takto na záležitost nahlíží i J. Petrov, podle nějž bylo zařazení prrírody a životního prostředí do výčtu prevenční klauzulí chráněných hodnot zbytečné, a to s odkazem na již diskutovaný fakt, že z občanskoprávního hlediska nejsou nevlastněné (i nevlastnitelné) části životního prostředí relevantní. ${ }^{72}$ Opačný postoj lze nalézt u I. Průchové, která vypuštění zmínky o životním prostředí považuje za nepochopitelné s ohledem na zařazení práva žít v příznivém životním prostředí do rámce ochrany osobnosti. Zdůrazňuje proto potřebu ,generálního apelu zákonodárce na každého, aby se choval tak, aby při jeho konání nedocházelo k nedůvodné újmě právě i na životním prostředi“. ${ }^{73}$

Ztotožňuji se spíše s druhým citovaným názorem, nebot' ustanovení upravující prevenci by mělo pokrývat celou oblast chráněnou občanským zákoníkem, tedy včetně environmentálních souvislostí, zvláště když jsou nově v občanském právu výslovně zmiňovány v rámci ochrany osobnosti. ${ }^{74}$ Ostatně obecné povaze i formulaci $§ 2900$ občanského zákoníku by jistá proklamativnost výrazněji neuškodila a naopak by posílila jeho generální povahu. S případnou obtížnou vymahatelností by se jistě bylo možné smírit, ostatně je základním principem občanského práva, že kde není žalobce, není ani soudce. Dovoluji si též zmínit, že zákaz působit nedůvodnou újmu na životním prostředí by mohl být v některých případech ku pomoci při hledání prríčinné souvislosti v př́ípadech zprostředkované škody (tedy kdy dojde k poškození životního prostředí a v jeho důsledku poté i ke škodě na něčím majetku). Nevhodné je z pohledu historické metody interpretace i to, že došlo k vypuštění předmětné pasáže oproti starší právní úpravě, a to bez bližšího vysvětlení v důvodové zprávě, ostatně podobně chybí i zdůvodnění zařazení práva žít v příznivém životním prostředí do $\$ 81$ občanského zákoníku.

Pro praxi mohou být ale důležitější další změny, které úpravu generální prevence v rámci rekodifikace českého občanského práva postihly. Povinnost předcházet újmě se totiž týká pouze aktivně jednající osoby. ${ }^{75}$ Domnívám se, že z hlediska ochrany životního prostředí to není výraznější komplikace, nebot' povinnost prevence by se měla především týkat provozovatelů aktivit, s nimiž je spojeno riziko negativních environmentálních dopadů.

Prevenční povinnost je též nově podmíněna existencí okolností př́ípadu nebo zvyklostí soukromého života, které takový postup vyžadují. Generální prevence tedy již není tak obecná jako podle dřívější právní úpravy, je však nutno poznamenat, že i za její platnosti judikatura možný široký výklad omezovala potřebou zohlednit časové a místní

72 PETROV, J. Protiprávnost a obecná prevenční povinnost. Právní rozhledy, 2007, č. 20, s. 748.

73 PRŮCHOVÁ, I. - In: JANČÁŘOVÁ, I. - PEKÁREK, M. - PRŮCHOVÁ, I. Odpovédnost v právu životního prostředí-současný stav a perspektivy. Brno: Masarykova univerzita, 2013, s. 38.

74 Odpovídalo by to i definici formulované ještě za platnosti předešlého zákoníku Nejvyšším soudem. Podle něj lze občanskoprávní prevenci „,charakterizovat jako souhrn způsobů a forem předcházení ohrožení a porušování subjektivních občanských práv, tj. práv, která jsou upravována a chráněna normami občanského práva hmotného v objektivním smyslu“ - viz rozsudek Nejvyššího soudu ze dne 25. února 2003 spis. zn. 25 Cdo 618/2001.

75 Což je patrné z rozdílu v použitých formulacích $§ 415$ starého občanského zákoníku („,Každý je povinen počínat si tak, aby nedocházelo ke škodám...“) a § 2900 nového občanského zákoníku (,... je každý povinen počínat si při svém konání tak, aby nedošlo k nedůvodné újmě“), klíčové je tedy zařazení slov „při svém konání“ do nového ustanovení. 
okolnosti. ${ }^{76}$ Další změnou je to, že $§ 2900$ občanského zákoníku chrání pouze statky náležející jiné osobě, než je osoba povinná. ${ }^{77}$

\section{2 ŠKODA JAKO DŮSLEDEK PROVOZNÍ ČINNOSTI}

Hlavním nástrojem pro dovozování povinnosti nahradit způsobenou škodu je v př́ípadech s environmentálním kontextem speciální úprava objektivní odpovědnosti osob realizujících určité činnosti, které lze shrnout pod pojmem provoz. České právo rozlišuje dva typy této odpovědnosti, a to spojené s provozní činností vyznačující se určitou organizovaností (např. se jedná o obchodní závod) a zaměřením na výdělečnost. ${ }^{78}$ Dále je upravován provoz zvlášt' nebezpečný, který je charakterizován tím, že u něj ani při řádné péči nelze zcela vyloučit možnost, že dojde ke vzniku závažné škody. ${ }^{79}$ Důsledek rozlišení těchto dvou druhů provozů spočívá především v odlišném nastavení liberačních důvodů, které jsou v případě provozu zvlášt’ nebezpečného zřetelně přísnější a pokrývají pouze okolnosti nezávislé na vůli provozovatele.

Přitom právě ve vymezení liberačních důvodů došlo v novém občanském zákoníku k významným změnám, ${ }^{80}$ nebot' možnost liberace je u škody způsobené provozní činností nově podmíněna prokázáním, že provozovatel předmětné činnosti ,,vynaložil veškerou péči, kterou lze rozumně požadovat“‘. Nutnost vynaložit veškerou péči odpovídá ze strany provozovatele činnosti působící škodu i zásadám práva životního prostředí, především principům odpovědnosti původce a předcházení znečišt'ování již u zdroje. Pokud jde o rozumný rozsah této péče, důvodová zpráva uvádí, že překračuje rámec pouhého souladu s právními předpisy, na druhou stranu zdůrazňuje, že ,požadavky na provozovatele nemohou být kladeny jako přepjaté “ a „,musí odpovídat tomu, co se od jednajícího v daném oboru očekává jako opatrné jednání podle dosažené úrovně jednání i obecné zkušenosti". 81

Popsaná změna může mít i své praktické dopady na jednu ze známých a dlouhodobých občanskoprávních kauz s environmentálním prvkem, a to spory vedené státním podnikem Lesy České republiky, s. p., s provozovateli rozličných zdrojů znečišt’ování ovzduší, vůči nimž požaduje náhradu škody způsobené průmyslovými exhalacemi na lesních porostech.

76 Nejvyšší soud při své interpretaci § 415 starého občanského zákoníku konstatoval, že každý byl podle něj „povinen zachovávat vždy takový stupeñ bedlivosti (pozornosti), který lze po něm vzhledem ke konkrétní časové a mistni situaci rozumně požadovat a který - objektivně posuzováno - je způsobilý zabránit či alespoň co nejvice omezit riziko vzniku škod na životě, zdraví či majetku; uvedené ustanovení mu však neukládá povinnost předvídat každý v budoucnu možný vznik škody“ - viz rozsudek Nejvyššího soudu ze dne 25. února 2003 spis. zn. 25 Cdo 618/2001.

77 Viz dovětek ,jiného“ (míněno svoboda, život, zdraví nebo vlastnictví jiné osoby) na konci textu § 2900 občanského zákoníku.

78 Viz § 2924 občanského zákoníku.

79 Viz $\$ 2925$ občanského zákoníku.

80 Je pravda, že ve starém občanském zákoníku byly liberační důvody u odpovědnosti za škodu způsobenou provozní ćinností a odpovědnosti za škodu způsobenou provozem zvlášt' nebezpečným nastaveny nevhodným až nelogickým způsobem.

81 Důvodová zpráva k návrhu občanského zákoníku [online]. Sněmovní tisk č. 362/0 z 6. volebního období Poslanecké snémovny Parlamentu České republiky [cit. 7. 10. 2017].

Dostupné z: https://www.psp.cz/sqw/text/tiskt.sqw?O=6\&CT=362\&CT1=0, s. 1120. 
V poslední době se totiž objevily rozsudky, dosud na úrovni druhé instance, v nichž soudy dopřály sluchu argumentům znečištovatelů, že realizovaná opatření ke snížení imisí představují náležitý důvod pro liberaci. ${ }^{82}$ Např́íklad Krajský soud v Praze v této souvislosti uvedl, že ,jedná se o liberaci, která je př́pustná v prípadě, že žalovaný prokáže, že učinil všechna opatření, aby minimalizoval škodu. Jsme toho názoru, že žalovaný tak čini napríklad spalováním pelet, přidáváním vápence apod."83 Předmětná soudní rozhodnutí však požadovanou výší náhrady škody nepřekročila hranici pro př́ípustnost dovolání, ${ }^{84}$ a proto tyto kauzy zatím nemohou přispět $\mathrm{k}$ tomu, aby se $\mathrm{k}$ nové právní úpravě a jejím důsledkům pro již dlouhodobě ustálený mechanismus náhrad škod na lesních porostech mohl vyjádřit Nejvyšší soud. Ten zatím v rozhodnutí vydaném na začátku roku 2018 zastával setrvalý postoj a argumentoval ustálenou rozhodovací praxí. 85

Pokud by se nový trend založený na nově formulovaném liberačním důvodu z povinnosti nahradit škodu z provozní činnosti prosadil, mohlo by to dle mého názoru posílit motivaci znečištovatelů provádět potřebná opatření ke snižování množství jimi vypouštěných emisí. S ohledem na prioritu prevence v ochraně životního prostředí se situace, kdy ke znečištění vůbec nedojde nebo pouze ve zmenšeném rozsahu, jeví ideální. Bude však pochopitelně záležet na způsobu, jakým se civilní soudy k problematice postaví, tedy jaký budou prostřednictvím své interpretace pojmu „,veškerá péče, kterou lze rozumně požadovat" vytvářet na entity provozující znečišt'ující aktivity tlak.

Ke změně dlouhodobě zastávaných postojů se zřejmě schyluje i v otázce zjednodušených metod prokazování způsobení škody na lesních porostech a určení její výše. Soudy totiž dlouhodobě zastávaly postoj, že s ohledem na nemožnost objektivního určení výšs škody ani prokázání prríčinné souvislosti mezi činností vedoucí k emisím a konkrétními škodami postačí k určení podílu jednoho znečištovatele na celkové škodě i zjednodušený postup, $\mathrm{v}$ daném př́ípadě $\mathrm{s}$ využitím Gaussova rozptylového modelu. ${ }^{86}$ V současné době dochází ke zpochybňování těchto závěrů. ${ }^{87}$

82 Rozsudek Krajského soudu v Praze ze dne 16. srpna 2017 spis. zn. 25 Co 231/2017 a rozsudek Krajského soudu v Českých Budějovicích ze dne 25. ledna 1018 spis. zn. 22 Co 1815/2017.

83 Rozsudek Krajského soudu v Praze ze dne 16. srpna 2017 spis. zn. 25 Co 231/2017 - citováno dle REICHL, J. Energetické firmy se bouří proti tomu, jak Lesy ČR vyčíslují škody na porostech. Česká justice [online], 16. 8. 2017 [cit. 4. 6. 2018]. Dostupné z: http://www.ceska-justice.cz/2017/08/energeticke -firmy-se-bouri-proti-tomu-jak-lesy-cr-vycisluji-skody-na-porostech. Žalovaným v tomto př́padě byla společnost ŠKO-ENERGO, s. r. o., závodní energetika automobilky Škoda Auto.

84 Ve smyslu § 238 odst. 1 písm. c) zákona občanského soudního řádu, tedy náhrada škody nepřekročila částku 50 tisíc Kč.

85 Usnesení Nejvyššího soudu ze dne 4. ledna 2018 spis. zn. 25 Cdo 5187/2017. Byla proti němu podána ústavní stížnost, kterou však Ústavní soud svým usnesením ze dne 7. února 2019 spis. zn. III. ÚS 1066/18 odmítl. Na tomto postoji Ústavní soud setrval i v následujícím skutkově obdobném př́padě - viz usnesení ze dne 20. února 2019 spis. zn. II. ÚS 341/19.

86 Rozsudek Nejvyššího soudu ze dne 19. prosince 2001 spis. zn. 25 Cdo 62/2000.

87 Svým usnesením ze dne 25. ř́jna 2017 spis. zn. 72 Co 227/2017 (jeho obsah popsán v TUŽINSKÝ, M. HÁJEK, M. Ve sporech o náhradu škody na lesích dochází k posunu. Energetika: odborný časopis pro elektrárenství, teplárenství a použití energie, 2018, č. 2, s. 75). Městský soud v Praze zrušil prvoinstanční rozsudek, jenž se držel výše popsaného ustáleného postupu, přičemž uložil soudu prvního stupně, aby si vyžádal revizní znalecký posudek a aby ve svém novém rozhodnutí jasně vyložil, které konkrétní skutečnosti související s předmětným sporem má za prokázané. Na to Obvodní soud pro Prahu 5 reagoval rozsudkem ze dne 17. července 2018 č. j. 55 C 114/2008-1257, v němž svůj přechozí postoj dále argumentačně doplnil (viz Obrat ve sporech o náhradu imisní škody na lesích. Prumyslovaekologie.cz [online], 4. 10. 2018 [cit. 30. 12. 2018]. Dostupné z: http://www.prumyslovaekologie.cz/Dokument/104617/obrat 
I v tomto př́ípadě zůstává další vývoj otázkou, a proto nelze ani předvídat důsledky, jaké by revize dosavadní metodiky prokazování škod na lesních porostech mohla mít. Pokud by vedla $\mathrm{k}$ tomu, že $\mathrm{v}$ návaznosti na výše zmiňovaný postoj Nejvyššího soudu budou soudy usilovat o nalezení modernějšího způsobu prokazování škod, který bude odpovídat současným vědeckým možnostem, bylo by to jistě legitimní. Považoval bych však za neštastné, pokud by došlo pouze ke zkomplikování procesu vyvozování povinnosti k náhradě škody, nebot' takový závěr by mohl negovat dosavadní pozitivní přínosy a motivační působení za účelem snižování množství emisí vyplývající z ukládaných náhrad i z nového liberačního důvodu. Na druhou stranu je třeba připustit, že s ohledem na šiři uplatnění náhrady škody způsobené provozem (provozní činností nebo provozem zvlášs' nebezpečným) environmentální aspekty této problematiky stěží mohou hrát prim při formulování obecných principů aplikace tohoto institutu. Př́ípadné úvahy de lege ferenda by tedy měly směřovat především do oblasti veřejného práva a ke korekci soukromoprávní úpravy by mělo být přistupováno velmi obezřetně.

\section{ZÁVĚR}

Účelem tohoto článku bylo pokusit se nabídnout alternativní pohled na ochranu životního prostředí, který by mohl být využit $\mathrm{k}$ doplnění převažujících přístupů. V rámci toho byla hledána odpověd' na otázku, zda a jakými způsoby mohou být nástroje soukromého práva, které slouží k ochraně a prosazování soukromých zájmů individuálních osob, využity $\mathrm{k}$ ochraně životního prostředí.

$\mathrm{Z}$ provedených rozborů předmětných soukromoprávních nástrojů dle mého názoru vyplývají některé jejich charakteristiky, které pokládám za pozitivní z hlediska jejich využitelnosti k ochraně životního prostředí.

$\mathrm{V}$ tomto směru považuji za vhodnou již samotnou koncepci právní úpravy, která se ve všech třech hlavních oblastech, na něž je tato práce zaměřena, vyznačuje relativní stručností a obecností, nebot' takové řešení umožňuje i pro dlouhodobě aplikované právní instituty nacházet nové způsoby uplatnění, a to včetně environmentální ochrany. Jejich použití k ochraně životního prostředí nemusí být na překážku ani skutečnost, že samotný pojem životní prostředí se v textu občanského zákoníku vyskytuje minimálně, v relevantním kontextu vlastně pouze jednou.

Důsledkem toho je značný prostor pro aplikační praxi, především pro soudy, aby zákonem stanovená pravidla konkretizovaly svým výkladem pro potřeby jednotlivých př́ípadů, a nalezly tak spravedlivé řešení odpovídající konkrétním okolnostem. Role a př́stup soudů se přitom jeví obecně pozitivní a jejich rozhodovací praxe napomáhá zpř́stupňovat či rozšiřovat aplikovatelnost ustanovení, která původně sloužila $\mathrm{k}$ jiným účelům nebo vůbec $\mathrm{k}$ ochraně životního prostředí nepřihlížela.

Jedním z témat, která rezonují právní úpravou i judikaturou v oblasti sousedského práva i náhrady škody, je otázka ekonomických souvislostí regulovaných činností i vhodnosti či přměřenosti používaných opatření. Přestože obecně bývají ekonomic-

-ve-sporech-o-nahradu-imisni-skody-na-lesich.aspx). I proti tomuto rozhodnutí však bylo podáno odvolání. 
ké zájmy chápány jako protiklad vůči potřebám ekologickým, domnívám se, že jejich zohledňování je nezbytné, obzvláště v rámci soukromého práva, nebot' rozpor s ekonomickou realitou by mohl využitelnosti jeho nástrojủ k ochraně životního prostředí ubírat na legitimitě a být jí tak vlastně na škodu.

Lze ale na druhou stranu pozitivně hodnotit, že soukromé právo pamatuje i na ochranu života a zdraví v rámci zkoumaných nástrojů, nebot' se jedná z lidského pohledu o klíčové kritérium fungování životního prostř̌edí. Jsou to totiž témata, v nichž se prolíná biologická stránka člověka, pro niž představuje životní prostředí souhrn podmínek existence i dalšího vývoje. S ochranou života a zdraví souvisí především ochrana osobnosti, přičemž lze vzpomenout, že i právo na příznivé životní prostředí bývalo před přijetím nového občanského zákoníku zmiňováno jako jeden z jejích aspektů.

Výhodou některých analyzovaných soukromoprávních nástrojů je skutečnost, že jejich použití není omezeno pouze na osoby fyzické. Vzhledem k majetkovému základu práva na ochranu před imisemi (jedná se o součást ochrany vlastnictví) i náhrady škody (jakožto újmy na jmění) nejsou tato práva ani po hmotněprávní stránce vázána na lidi jakožto biologické organismy. ${ }^{88}$

Hlavním znakem soukromoprávních nástrojů analyzovaných v této práci je to, že jejich použití je podmíněno individuální iniciativou dotčených osob. Výhodu spatřuji v nezávislosti na postupu správních orgánů a menší ovlivnitelnosti faktory, jako je politická situace či potřeby národního hospodářství, naopak za nevýhody lze považovat podmíněnost použití těchto nástrojů osobním zájmem i možností a ochotou absolvovat spor před soudem, absenci koncepčních nástrojů či nemožnost reagovat na rozsáhlejší problémy životního prostředí, nebot' ty nejsou řešitelné na půdorysu sporu žalobce proti žalovanému.

S ohledem na výše uvedené se domnívám, že soukromé právo nabízí nástroje, které lze využít různými způsoby $\mathrm{k}$ ochraně životního prostředí. A to i presto, že budou uplatňovány při prosazování individuálních práv a zájmů. Je však na druhou stranu tř̌eba přiznat, že ochrana poskytovaná soukromým právem je pouze nepřímá a určitě není komplexní, a proto ochranu poskytovanou životnímu prostředí specializovanými veřejnoprávními prostředky a právními úpravami nahradit nemůže. Životní prostředí je ale natolik nenahraditelnou hodnotou, že je žádoucí k jeho ochraně využít všech disponibilních prostředků a $\mathrm{v}$ tomto směru mohou soukromoprávní nástroje při správném uplatnění sehrát cennou úlohu.

Jedná se zároveň i o problematiku stále aktuální, nebot' dosud ještě nebyly vyhodnoceny všechny změny, které přinesla rekodifikace českého občanského práva, a všechny možnosti, které nový občanský zákoník nabízí. Stejně tak aplikační praxe, především na úrovni rozhodování soudů, u řady institutů stále hledá optimální postoj, na němž by se mohla judikatura ustálit. Proto se domnívám, že problematika využívání soukromoprávních nástrojů $\mathrm{k}$ ochraně životního prostředí bude i v budoucnu nabízet řadu témat, která bude zajímavé sledovat.

JUDr. Bc. Jan Vévoda, Ph.D.

Ministerstvo vnitra ČR

JanVevoda@seznam.cz

88 Viz usnesení Ústavního soudu ze dne 6. ledna 1998 spis. zn. I. ÚS 282/97. 